\title{
Pengaruh Dukungan Sosial Keluarga Terhadap Perilaku Warga Binaan Pemasyarakatan di Lapas Kelas I Makassar
}

\author{
The Influence of Family Social Support on the Behavior of Prisoners in \\ Penitentiary Class I Makassar
}

\section{Andi Anriyadi}

${ }^{1}$ Mahasiswa Sosiologi Fisip Universitas Hasanuddin, Makassar, Indonesia, email: andiandriyadi777@gmail.com

\section{A R T I C L E I N F O}

\section{How to Cite:}

Anriyadi, A. (2020).Pengaruh Dukungan Sosial Keluarga Terhadap Perilaku Warga Binaan Pemasyarakatan di Lapas Kelas I Makassar. Hasanuddin Journal of Sociology (HJS), 2(1), 73-87

\section{Keywords:}

emotional support, instrumental, information, motivational and behavior of the assisted residents

\section{Kata Kunci :}

dukungan emosional, instrumental, informasi, motivasional dan perilaku warga binaan

\begin{abstract}
A B S T RA C T
Along with technological advances and the development of human civilization from time to time, the needs of human interests are increasing, this certainly has a negative impact that results in an increased possibility of crime, individuals who commit acts of violation of the law will get sanctions. Prison punishment is a function to sensitize individuals from crime and not to repeat in the future and individuals serving a sentence in a Penitentiary. Therefore, the family needs to provide social support that can help prisoners feel calm, cared for, loved and raises confidence. Family social support consists of: emotional support, instrumental support, information support and motivational support that affect prisoners' acceptance. This research uses a quantitative approach, which explains the relationship between research variables through testing the hypothesis that has been formulated. Data collection is carried out through the distribution of questionnaires. The results obtained by the findings that family social support in terms of emotional support has a positive and significant effect on the behavior of fostered citizens, instrumental support has a positive and significant effect on the behavior of prisoners, information support has a positive and significant effect on the behavior of prisoners, and motivational support has a positive and significant effect on the behavior of prisoners in Class I Prison Makassar
\end{abstract}

\section{A B S T R A K}

Seiring dengan kemajuan teknologi dan perkembangan peradaban manusia dari masa ke masa, kebutuhan kepentingan manusia semakin bertambah, hal ini tentunya membawa dampak negatif yang mengakibatkan bertambahnya kemungkinan terjadinya kejahatan, individu yang melakukan tindak pelanggaran hukum akan mendapatkan sanksi. Pidana penjara merupakan fungsi untuk menyadarkan individu dari tindak kejahatan dan tidak mengulangi di masa yang akan datang dan individu 
dalam menjalani masa hukuman di Lembaga Pemasyarakatan. Oleh karena itu maka pihak keluarga perlu memberikan dukungan sosial yang dapat membantu narapidana merasa tenang, diperhatikan, dicintai dan menimbulkan rasa percaya diri. Dukungan sosial keluarga terdiri dari : dukungan emosional, dukungan instrumental, dukungan informasi dan dukungan motivasi yang mempengaruhi penerimaan kembali narapidana. Penelitian ini menggunakan pendekatan kuantitatif, yang menjelaskan hubungan antara variabel-variabel penelitian melalui pengujian hipotesis. Pengumpulan data dilakukan melalui penyebaran kuesioner yang diberikan kepada Warga Binaan pemasyarakatan yang telah ditentukan. Hasil penelitian diperoleh temuan bahwa dukungan sosial keluarga ditinjau dari dukungan emosional berpengaruh positif dan signifikan terhadap perilaku warga binaan, dukungan instrumental berpengaruh positif dan signifikan terhadap perilaku warga binaan pemasyarakatan, dukungan informasi berpengaruh positif dan signifikan terhadap perilaku warga binaan pemasyarakatan, serta dukungan motivasional berpengaruh positif dan signifikan terhadap perilaku warga binaan pemasyarakatan di Lapas Kelas I Makassar.

\section{PENDAHULUAN}

Seiring dengan kemajuan teknologi dan perkembangan peradaban manusia dari masa ke masa, kebutuhan kepentingan manusia semakin bertambah, hal ini tentunya membawa dampak negatif yang mengakibatkan bertambahnya kemungkinan terjadinya kejahatan. Manusia dalam memenuhi kebutuhan hidupnya yang beraneka ragam sering menghalalkan berbagai cara tanpa mengindahkan norma-norma hukum yang berlaku dalam masyarakat. Dengan demikian sampai saat ini kejahatan masih tetap abadi dan bahkan akan berkembang sesuai perkembangan peradaban dari masa ke masa.

Kriminalitas atau kejahatan merupakan bentuk perilaku pelanggaran aturan sosial yang diterapkan oleh badan hukum. Tingkah laku kriminal dapat dilakukan oleh siapa saja, kapan saja dan dimana saja baik pria atau waita, dapat berlangsung pada usia anak-anak, remaja, dewasa bahkan lanjut usia. Menurut Lubis dan Maslihah (2012:2) yang mengemukakan bahwa individu yang melakukan tindak pelanggaran hukum akan mendapatkan sanksi. Sanksi dapat berasal dari adat, agama, negara bahkan dari masyarakat. Pidana penjara merupakan fungsi untuk menyadarkan individu dari tindak kejahatan dan tidak mengulangi di masa yang akan datang dan individu dalam menjalani masa hukuman di Lembaga Pemasyarakatan dan individu yang mengalami hukuman di lembaga pemasyarakatan disebut dengan Narapidana.

Narapidana yakni seseorang yang tengah menjalani masa tahanan di lembaga pemasyarakatan atas tindak kejahatan yang telah diperbuat. UU. No. 12 tahun 1995 merupakan terpidana yang menjalani pidana hilang kemerdekaan di Lembaga pemasyarakatan (Lapas). Lembaga Pemasyarakatan yang merupakan tempat untuk melakukan pembinaan narapidana dan anak didik pemasyarakatan. Narapidana yang berada di Lapas diberikan pembinaan, dengan konsep rehabilitasi dan reintegrasi 
sosial, agar narapidana menyadari kesalahannya, memperbaiki diri, tidak melakukan tindak pidana dan kembali menjadi warga masyarakat yang bertanggungjawab bagi diri, keluarga dan lingkungan (UU. No. 12 tahun 1995).

Status sebagai narapidana merupakan stressor yang tergolong berat dalam kehidupan karena kehilangan kebebasan, rasa aman, nyaman, terpisah dari keluarga dan komunikasi sebelumnya. Oleh karena itulah sangat diperlukan oleh adanya dukungan sosial yaitu keluarga yang mau menerima, menurut Sarafino dalam Smet (1994:136) yang mengemukakan bahwa dukungan sosial merupakan sesuatu mengacu pada kesenangan yang dirasakan, penghargaan akan kepedulian atau membantu orang menerima dari orang-orang atau kelompok-kelompok lain. Sehingga dari pendapat yang dikemukakan oleh Sarafino dalam Smet (1994) maka dapat dikatakan bahwa dukungan sosial sangat dibutuhkan oleh warga binaan sebab merupakan modal beradaptasi dengan lingkungan yang terbatas sehingga terutama berkurangnya rasa percaya diri dan rasa kurang dihargai.

Wibowo (2013:40) yang mengemukakan bahwa dukungan sosial diberikan dapat membantu narapidana merasa tenang, diperhatikan, dicintai dan menimbulkan rasa percaya diri. Dengan adanya dukungan sosial terutama keluarga akan membantu narapidana dalam mengatasi masalah psikis yang rentang terjadi pada narapidana. Dari pendapat yang dikemukakan oleh Wibowo (2013) maka dapat dikatakan bahwa dukungan sosial merupakan faktor yang sangat berpengaruh bagi narapidana. Hal ini didukung oleh penelitian yang dilakukan oleh Noor (2016) yang menemukan bahwa dukungan keluarga yang diberikan dalam bentuk berbeda-beda antara lain komunikasi verbal dan non verbal membuat narapidana lebih berani dan tenang dalam menghadapi semua proses yang terjadi.

Review dari penelitian sebelumnya yaitu Permadin (2018) yang menemukan bahwa terdapat hubungan yang signifikan positif dukungan keluarga dengan narapidana di Lapas. Sedangkan Yulianingsih (2017) yang menunjukkan bahwa dukungan sosial keluarga yang terdiri dari : dukungan emosional, dukungan instrumental dan dukungan motivasi yang mempengaruhi penerimaan kembali narapidana. Perbedaan peneliltian yang dilakukan oleh Permadin (2018) dan Yulianingsih (2017) dimana penelitian yang dilakukan Permadin (2018) yang meneliti pada pengaruh dukungan sosial terhadap warga binaan, sedangkan Yulianingsih (2017) yang mengukur pengaruh dukungan sosial terhadap perilaku narapidana. Kemudian penelitian yang dilakukan oleh peneliti lebih menekankan pada pengaruh dukungan sosial terhadap perilaku narapidana. Alasannya karena peneliti berpedoman dengan hasil penelitian yang dilakukan oleh Noor (2016) bahwa dukungan keluarga dapat membuat narapidana lebih berani dan tenang dalam menghadapi proses yang terjadi.

Penelitian ini difokuskan pada Lembaga Pemasyarakatan, hal ini didasari dari permasalahan dimana terjadi over capacity. Menurut data dan Situs Dirjen Lembaga Pemasyarakatan bahwa 29 kantor wilayah 
dari 33 kantor wilayah Kementerian Hukum dan Ham, artinya hanya Sembilan LP yang cukup menampung penghuni, baik tahanan maupun narapidana. Keputusan ini sudah termasuk pembangunan 14 LP baru yang dilakukan pada masa Menteri Hukum dan HAM bahwa saat ini total lembaga pemasyarakatan di Indonesia mencapai 442.

Salah satu lembaga pemasyarakatan di Indonesia adalah Lembaga Pemasyarakatan yang saat ini menampung sebanyak 170 orang tahanan dan 608 orang narapidana. Sehingga jumlah keseluruhan warga binaan yang berada di lembaga pemasyarakatan kelas I kota Makassar berjumlah sebanyak 778 orang sehingga tahanan maupun narapidana tidak bisa dikoordinir dengan baik oleh pihak Lembaga Pemasyarakatan Kelas I kota Makassar. Oleh karena itu tahanan maupun narapidana memerlukan dukungan ekstra dari pihak keluarga.

Fenomena yang terjadi selama ini bahwa jumlah kasus kriminalitas di kota Makassar menduduki rangking 1, dimana kejadian dari bulan Januari s/d Desember tahun 2018 angka kriminalitas meningkat dengan jumlah angka kejahatan tercatat sebanyak 378 kasus. Angka tersebut menempatkan Makassar pada peringkat pertama dibandingkan dengan daerah lainnya di Sulawesi Selatan. Kejahatan yang tercatat terdiri dari kasus penganiayaan berat, pembunuhan pencurian dengan kekerasan, pencurian kendaraan bermotor, pencurian hewan ternak hingga kasus narkoba meningkat untuk setiap tahunnya. Sehingga dengan adanya jumlah kasus yang meningkat untuk setiap tahun maka sangat ditentukan oeh adanya dukungan sosial.

\section{KAJIAN LITERATUR}

\section{Narapidana}

Narapidana adalah terpidana yang menjalani pidana hilang kemerdekaan di Lembaga Pemasyarakatan, Tujuan narapidana di masukkan ke Lembaga pemasyarakatan, disamping memberikan perasaan lega terhadap korban juga memberikan keresahan di masyarakat. Caranya yaitu dengan memberikan mereka pembinaan jasmani maupun rohani. Selama kehilangan kemerdekaan bergerak ia harus dikenalkan dengan masyarakat dan tidak boleh diasingkan. Narapidana diayomi dengan memberikan bekal hidup sebagai waraga yang berguna dalam masyarakat. Pembinaan Perilaku di indonesia dilaksanakan sebuah sistem, yang dikenal dengan sistem pemasyarakatan. Menurut Purnomo (2016 : 180) Narapidana adalah seorang manusia anggota masyarakat yang dipisahkan dari induknya dan selama waktu tertentu itu diproses dalam lingkungan tempat tertentu dengan tujuan, metode, dan sistem pemasyarakatan. 


\section{Pengertian Lembaga Pemasyarakatan}

Lembaga pemasyarakatan adalah sebagai salah satu alat revolusi dalam mencapai masyarakat sosialis Indonesia, diresapi oleh ide pengayoman dan bertujuan membimbing dan mendidik narapidana agar menjadi peserta aktif dan menjadi lebih baik dalam hidup bermasyarakat. Dengan menyadari bahwa tiap manusia adalah mahluk tuhan yang hidup bermasyarakat maka dalam sistem pemasyarakatan Indonesia para Narapidana di integrasikan dengan masyarakat dan diikut sertakan dalam pembangunan ekonomi negara secara aktif dan ofensif agar dapat menimbulkan diantara mereka rasa turut bertanggung jawab dalam usaha membangun negara agar lebih maju. Pemasyarakatan yang merupakan bagian akhir dari sistem pemidanaan dalam tata peradilan pidana adalah bagian integral dari tata peradilan terpadu (integratedcriminal justice system). Dengan demikian, pemasyarakatan baik ditinjau dari sistem, kelembagaan, cara pembinaan, dan petugas pemayarakatan, merupakan bagian yang tak terpisahkan dari suatu rangkaian proses penegakan hukum.

\section{Pengertian Dukungan Sosial}

Dukungan Sosial adalah informasi atau umpan balik dari orang lain yang menunjukkan bahwa seseorang dicintai dan diperhatikan, dihargai, dan dihormati, dan dilibatkan dalam jaringan komunikasi dan kewajiban yang timbal balik (King, 2012 : 226). Sedangkan menurut Ganster, dkk. (dalam Apollo \& Cahyadi, 2012: 261) dukungan sosial adalah tersedianya hubungan yang bersifat menolong dan mempunyai nilai khusus bagi individu yang menerimanya. Dukungan sosial menurut Cohen \& Syme (dalam Apollo \& Cahyadi, 2012: 261) adalah sumber-sumber yang disediakan orang lain terhadap individu yang dapat mempengaruhi kesejahteraan individu bersangkutan. Lebih lanjut dukungan sosial menurut House \& Khan (dalam Apollo \& Cahyadi, 2012: 261) adalah tindakan yang bersifat membantu yang melibatkan emosi, pemberian informasi, bantuan istrumen, dan penilaian positif pada individu dalam menghadapi permasalahannya. Menurut Cohen \& Hoberman (dalam Isnawati \& Suhariadi, 2013: 3) dukungan sosial mengacu pada berbagai sumber daya yang disediakan oleh hubungan antar pribadi seseorang.

\section{Sumber-Sumber Dukungan Sosial}

Sumber-sumber dukungan sosial menurut Goldberger \& Breznitz (dalam Apollo \& Cahyadi, 2012: 261) adalah orang tua, saudara kandung, anak-anak, kerabat, pesangan hidup, sahabat rekan sekerja, dan juga tetangga. Hal yang sama juga diungkapkan oleh Wentzel dalam (Apollo \& Cahyadi, 2012 : 261) bahwa sumber-sumber dukungan sosial adalah oarang-orang yang memiliki hubungan yang berarti bagi individu, seperti keluarga, teman dekat, pasangan hidup, rekan sekerja, saudara, dan tetangga, 
teman-teman dan guru disekolah. Sedangkan menurut Tarmidi \& Kambe (2010: 217-218) dukungan sosial dapat diaplikasikan ke dalam lingkungan keluarga, yaitu orang tua. Jadi dukungan sosial orang tua adalah dukungan yang diberikan oleh orang tua kepada anaknya baik secara emosional, penghargaan, informasi atau pun kelompok. Dukungan orang tua berhubungan dengan kesuksesan akademis remaja, gambaran diri yang positif, harga diri, percaya diri, motivasi dan kesehatan mental. Dukungan sosial orang tua dapat dibagi menjadi dua hal, yaitu dukungan yang bersifat positif dan dukungan yang bersifat negatif. Dukungan positif adalah perilaku positif yang ditunjukkan oleh orang tua, dukungan yang bersifat negatif adalah perilaku yang dinilai negatif yang dapat mengarahkan pada perilaku negatif anak

\section{Pengertian Keluarga}

Keluarga adalah unit terkecil dari masyarakat yang terdiri atas kepala keluarga dan beberapa orang yang terkumpul dan tinggal di suatu tempat di bawah suatu atap dalam keadaan saling ketergantungan. Peranan keluarga menggambarkan seperangkat perilaku antar pribadi, sifat, kegiatan yang berhubungan dengan pribadiu dalam posisi dan situasi tertentu. Dalam peranan pribadi dalam keluarga didasari oleh harapan dan pola perilaku dari keluarga, kelompok dan masyarakat. Menurut Syamsu Yusuf (2011 : 35-36) mengatakan bahwa keluarga dapat diartikan dua macam, yaitu pertama dalam arti luas, keluarga meliputi semua pihak yang ada hubungan darah atau keturunan yang dapat dibandingkan dengan " clan " atau marga. Kedua dalam arti sempit keluarga meliputi orang tua dan anak.

Dari pengertian para ahli, dapat disimpulkan bahwa "keluarga" merupakan suatu kelompok sosial kecil yang didalamnya terdiri dari seorang ibu, ayah dan anak dan dapat berkembang sehingga membentuk keluarga yang baru. Keluarga dalam kamus Oxford Leaner's Pocket Dictionary berasal dari kata family yang berarti group consisting of one or two parents and t heir children (kelompok yang terdiri dari satu atau dua orang tua dan anak-anak mereka) (Helmawati, 2014: 41-42).

\section{Dukungan Sosial Keluarga}

Dukungan sosial (Social Support) adalah suatu bentik perhatian, penghargaan, semangat, penerimaan maupun pertolongan dalam bentuk lainnya yang berasal dari orang yang memiliki hubungan sosial dekat, seperti orang tua, saudara, anak, sahabat, teman ataupun orang lain dengan tujuan membantu seseorang saat mengalami permasalahan. Bentuk dukungan tersebut dapat berupa informasi, tingkah laku tertentu maupun materi yang bisa menjadikan individu dapat menerima bantuan, merasa disayangi, perhatian dan bernilai. Penelitian yang dilakukan Nurfika Asmaningrum dkk (2014) 
menyatakan bahwa dukungan sosial keluarga merupakan dukungan sosial yang dapat dijangkau oleh keluarga. Dukungan sosial keluarga sangat dibutuhkan oleh seseorang yang menjadi anggota keluarga dalam hal ini narapidana karena keluarga merupakan sumber dukungan sosial terdekat yang paling mengetahui kebutuhan akan anggota keluarganya.

\section{Perilaku Warga Binaan Pemasyarakatan}

Perilaku yang tidak sesuai dengan aturan hukum dan Undang-Undang akan membawa seseorang berurusan dengan Hukum dan Peradilan. Kelanjutannya akan berakibat pada masuknya seseorang kedalam penjara sebagai tanggung jawab dari perilaku melanggar hukum yang telah dilakukannya. Berbagai masalah pelanggaran hukum oleh sebagian besar orang menjadi aib yang memalukan baik bagi dirinya, keluarga, maupun orang yang telah berhubungan dengan orang tersebut.

Skiner berpendapat (dalam Notoatmodjo 2012 : 134) dilihat dari bentuk respons terhadap stimulus ini, maka perilaku dapat dibedakan menjadi dua yaitu: a. Perilaku tertutup (convert behavior). Respons seseorang terhadap stimulus dalam bentuk terselubung atau tetutup (convert). Respons atau reaksi terhadap stimulus ini masih terbatas pada perhatian, persepsi, pengetahuan / kesadaran, dan sikap yang terjadi pada orang yang menerima stimulus tersebut, dan belum diamati secara jelas oleh orang lain. Oleh sebab itu, disebut convert behavior, dan b. Perilaku terbuka (overt behavior). Respons seseorang terhadap stimulus dalam bentuk tindakan nyata atau terbuka. Respons terhadap. Respons terhadap stimulus tersebut sudah jelas dalam bentuk tindakan atau praktik (practice), yang dengan mudah dapat diamati atau dilihat oleh orang lain. Oleh sebab itu disebut overt behavior. Seperti telah disebutkan di atas, sebagian perilaku manusia adalah operant response.

\section{METODE PENELITIAN}

\section{Lokasi dan Rancangan Penelitian}

Penelitian ini dilaksanakan pada Lembaga Pemasyarakatan Kelas I Makassar, berlokasi di Jalan Sultan Alauddin, Gunung Sari, Kecamatan. Rappocini, Kota Makassar, Sulawesi Selatan. Rancangan dalam penelitian ini adalah rancangan kuantitatif, karena penelitian ini disajikan dengan angka-angka. Hal ini sesuai dengan pendapat Arikunto (2014: 12) yang mengemukakan penelitian kuantitatif adalah pendekatan penelitian yang banyak dituntut menggunakan angka, mulai dari pengumpulan data, penafsiran terhadap data tersebut, serta penampilan hasilnya. Penelitian ini berusaha menjelaskan hubungan antara variabel-variabel penelitian melalui pengujian hipotesis yang telah dirumuskan. Hubungan yang akan dijelaskan dalam penelitian ini adalah Pengaruh Dukungan Sosial Keluarga Terhadap Perilaku Warga Binaan Pemasyarakatan di Lapas Kelas I Makassar. 


\section{Populasi dan Sampel}

Populasi adalah wilayah generalisasi yang terdiri atas: obyek/ subyek yang mempunyai kualitas dan karakteristik tertentu yang ditetapkan oleh peneliti untuk dipelajari dan kemudian ditarik kesimpulannya (Sugiyono, 2016). Adapun yang menjadi populasi dalam penelitian ini adalah penghuni Lembaga Pemasyarakatan yang berjumlah sebanyak 778 orang, hal ini dapat diperincikan tahanan sebesar 170 orang dan 608 orang narapidana. Untuk menentukan jumlah sampel maka digunakan rumus slovin sehingga diperoleh jumlah sampel sebanyak 89 orang responden, teknik penarikan sampel dengan menggunakan metode non probability sampling yakni penentuan sampel dengan tidak memberikan peluang yang sama pada populasi, jadi dalam penelitian ini khusus warga binaan pemasyarakatan di Lapas Kelas I Makassar.

\section{Metode Pengumpulan Data}

Dalam penelitian ini metode pengimpulan data yang digunakan adalah sebagai berikut: 1. Angket atau Kuesioner, yakni instrumen penelitian yang berupa daftar pertanyaan untuk memperoleh keterangan dari sejumlah responden (sumber yang diambil datanya melalui angket). 2 Metode observasi, adalah proses pengamatan dan pencatatan secara sistematis mengenai gejala-gejala yang diteliti, 3. Wawancara, adalah merupakan pertemuan antara dua orang untuk bertukar informasi dan ide melalui tanya jawab sehingga dapat dikontruksikan makna dalam suatu topik tertentu.

\section{Metode Analisis Data}

Metode analisis yang digunakan dalam penelitian ini adalah sebagaii berikut :

1. Statistik deskriptif memberikan gambaran atau deskripsi suatu data yang dilihat dari nilai rata-rata (mean), standar deviasi, varian, maksimum, minimum, range, kurtosis dan skewness (kemencengan distribusi), (Ghozali, 2018).

2. Uji Kualitas Data

a. Uji Validitas

Uji validitas dalam penelitian ini digunakan untuk mengukur sah atau valid tidaknya suatu kuesioner. Suatu kuesioner dikatakan valid jika pertanyaan pada kuesioner mampu mengungkapkan sesuatu yang akan diukur oleh kuesioner tersebut. (Ghozali, 2018).

b Uji Realibilitas

Uji Reliabilitas adalah alat untuk mengukur suatu kuesioner yang merupakan indikator dari 
variabel atau konstruk. Suatu kuesioner dikatakan reliabel atau handal jika jawaban dari seseorang terhadap pernyataan adalah konsisten atau stabil dari waktu ke waktu (Ghozali, 2018).

\section{Uji Hipotesis}

Dalam menguji hipotesis penelitian dengan menggunakan analisis regresi linier berganda, yang bertujuan untuk mengetahui pengaruh variabel bebas yaitu emosional $\left(\mathrm{X}_{1}\right)$, instrumental $\left(\mathrm{X}_{2}\right)$, informasi $\left(\mathrm{X}_{3}\right)$ dan motivasional (X4) terhadap perilaku warga binaan pemasyarakatan di Lapas Kelas I Makassar (Y). Adapun bentuk persamaan regresi linier berganda dikemukakan oleh Pardede dan Manurung (2014) adalah : $Y=\beta_{\mathrm{o}}+\beta_{1} \mathrm{X}_{1}+\beta_{2} \mathrm{X}_{2}+\beta_{3} \mathrm{X}_{3}+\beta_{4} \mathrm{X}_{4}+\mathrm{e}$

4. Uji Koefisiensi Determinasi $\left(\mathrm{R}^{2}\right)$

Koefisien determinasi $\left(\mathrm{R}^{2}\right)$ pada intinya mengukur seberapa jauh kemampuan model dalam menerangkan variasi variabel dependen (perilaku warga binaan). Dalam output SPSS, koefisien determinasi terletak pada tabel model summery $\mathrm{b}$ dan tertulis $\mathrm{R}$ square. Namun untuk regresi linier berganda sebaliknya menggunakan R square yang sudah disesuaikan atau tertulis adjusted R square, karena disesuaikan dengan jumlah variabel independen yang digunakan dalam penelitian.

\section{Uji Hipotesis}

\section{a. Simultan (Uji Statistik F)}

Uji statistik F pada dasarnya menunjukan apakah semua variabel independen atau bebas yang dimaksudkan dalam model mempunyai pengaruh secara bersama-sama terhadap variabel dependen/terikat (Ghozali,2018).

b. Uji Parsial (Uji t)

Uji statistik t pada dasarnya menunjukkan seberapa jauh pengaruh satu variabel penjelas secara individual dalam menerangkan variasi variabel terikat (Ghozali, 2018).

\section{HASIL PENELITIAN}

\section{Analisis Regresi Linear Berganda}

Analisis regresi linear berganda adalah suatu analisis untuk mengetahui pengaruh dukungan emosional, dukungan instrumental, dukungan informasi dan dukungan motivasional terhadap perilaku warga binaan pemasyarakatan di Lapas Kelas I Makassar. Sehingga dalam menganalisis data regresi yang diolah dengan menggunakan SPSS release 24, maka dapat disajikan tabel olahan data regresi yaitu sebagai berikut : 
Tabel 1. Hasil Olahan Data Regresi dengan SPSS release 24

\begin{tabular}{|c|c|c|c|c|c|}
\hline \multirow[b]{2}{*}{ Model } & \multicolumn{2}{|c|}{$\begin{array}{c}\text { Unstandardized } \\
\text { Coefficients }\end{array}$} & \multirow{2}{*}{$\begin{array}{c}\begin{array}{c}\text { Standardized } \\
\text { Coefficients }\end{array} \\
\text { Beta }\end{array}$} & \multirow[b]{2}{*}{$\mathrm{t}$} & \multirow[b]{2}{*}{ Sig. } \\
\hline & B & Std. Error & & & \\
\hline 1 (Constant) & -.074 & .465 & & -.160 & .874 \\
\hline Dukungan emosional & .247 & .070 & .292 & 3.514 & .001 \\
\hline Dukungan instrumental & .234 & .073 & .273 & 3.221 & .002 \\
\hline Dukungan informasi & .288 & .076 & .302 & 3.809 & .000 \\
\hline Dukungan Motivasional & .291 & .094 & .265 & 3.098 & .003 \\
\hline
\end{tabular}

a. Dependent Variable: Perilaku warga binaan pemasyarakatan

Sumber : Hasil olahan data SPSS release 24

Berdasarkan tabel hasil olahan data regresi yang telah diuraikan di atas, maka akan disajikan persamaan linear yaitu sebagai berikut : $\mathrm{Y}=-0,074$ bo $+0,247 \mathrm{X}_{1}+0,234 \mathrm{X}_{2}+0,288 \mathrm{X}_{3}+0,291 \mathrm{X}_{4}$. Dimana bo $=-0,074$ yang merupakan nilai konstanta, ini mengandung arti dengan mengabaikan variabel dukungan emosional, dukungan instrumental, dukungan informasi dan dukungan motivasional maka perilaku warga binaan pemasyarakatan akan menurun. $\mathrm{b}_{1}=0,247$, hal ini menunjukkan bahwa dukungan emosional mempunyai pengaruh positif terhadap perilaku warga binaan pemasyarakatan di Lapas Kelas I Makassar. $\mathrm{b}_{2}=0,234$, hal ini menunjukkan bahwa dukungan instrumental ber-pengaruh positif terhadap perilaku warga binaan pemasyarakatan di Lapas Kelas I Makassar, $b_{3}=0,288$, hal ini menunjukkan bahwa dukungan informasi mempunyai pengaruh positif terhadap perilaku warga binaan pemasyarakatan di Lapas Kelas I Makassar, serta $b_{4}=0,291$, hal ini berarti bahwa dukungan motivasional mempunyai pengaruh positif terhadap perilaku warga binaan pemasyarakatan di Lapas Kelas I Makassar.

\section{Pengujian Hipotesis}

\section{Uji t (t-test)}

Pengujian ini bertujuan untuk menguji signifikan hubungan antara variabel X (independen) dan variabel Y (dependen), atau menguji apakah masing-masing variabel-variabel independen yaitu : dukungan emosional, dukungan instrumental, dukungan informasi dan dukungan motivasional mempunyai pengaruh secara signifikan terhadap perilaku warga binaan pemasyarakatan di Lapas Kelas 
I Makassar. Uji t dilakukan dengan membandingkan antara nilai probabilitas dengan nilai standar. Apabila nilai probabilitas lebih kecil dari nilai standar, berarti memberikan pengaruh secara signifikan. Untuk hasil pengujian secara parsial antara variabel dukungan emosional, dukungan instrumental, dukungan informasi dan dukungan motivasional terhadap perilaku warga binaan pemasyarakatan di Lapas Kelas I Makassar. Berdasarkan hasil pengujian parsial dengan menggunakan program SPSS release 24 maka diperoleh hasil

1) Pengaruh dukungan emosional terhadap perilaku warga binaan pemasyarakatan

Dari hasil pengujian regresi diperoleh nilai probabilitas $0,001<0,05$, hal ini menunjukkan bahwa dukungan emosional berpengaruh signifikan terhadap perilaku warga binaan pemasyarakatan di Lapas Kelas I Makassar.

2) Pengaruh dukungan instrumental terhadap perilaku warga binaan pemasyarakatan

Dari hasil pengujian regresi diperoleh nilai probabilitas $0,002<0,05$, hal ini menunjukkan bahwa dukungan instrumental berpengaruh signifikan terhadap perilaku warga binaan pemasyarakatan di Lapas Kelas I Makassar.

3) Pengaruh dukungan informasi terhadap perilaku warga binaan pemasyarakatan

Dari hasil pengujian regresi diperoleh nilai probabilitas $0,000<0,05$, hal ini menunjukkan bahwa dukungan informasi berpengaruh signifikan terhadap perilaku warga binaan pemasyarakatan di Lapas Kelas I Makassar.

4) Pengaruh dukungan motivasional terhadap perilaku warga binaan pemasyarakatan

Dari hasil pengujian regresi diperoleh nilai probabilitas $0,003<0,05$, hal ini menunjukkan bahwa dukungan motivasional berpengaruh signifikan terhadap perilaku warga binaan pemasyarakatan di Lapas Kelas I Makassar.

\section{Uji F}

Untuk membuktikan sejauh mana pengaruh secara bersama-sama atau serempak antara dukungan emosional, dukungan instrumental, dukungan informasi dan dukungan motivasional terhadap perilaku warga binaan pemasyarakatan di Lapas Kelas I Makassar maka digunakan uji F. Dimana dapat dilakukan dengan membandingkan antara nilai signifikan dengan nilai standar $(0,05)$. Apabila nilai signifikan lebih kecil dari nilai standar berarti memberikan pengaruh secara bersama-sama atau serempak. Dari hasil olahan data statistik F (F-test) dengan menggunakan program SPSS, maka didapat nilai signifikan 0,000, karena nilai sign. $0,000<0,05$, maka dapat dikatakan bahwa dukungan emosional, dukungan instrumental, dukungan informasi dan dukungan motivasional berpengaruh secara serempak atau bersama-sama terhadap perilaku warga binaan pemasyarakatan di Lapas Kelas I 
Makassar. Hal ini berarti bahwa semakin baik dukungan sosial keluarga

melalui dukungan emosional, dukungan instrumental, dukungan informasi dan dukungan motivasional maka perilaku warga binaan pemasyarakatan di Lapas Kelas I Makassar akan semakin meningkat.

\section{PEMBAHASAN}

\section{1) Pengaruh dukungan emosional terhadap perilaku warga binaan}

Berdasarkan hasil analisis koefisien regresi maka diperoleh hasil statistik untuk dukungan emosional sebesar 0,247 serta memiliki nilai probabilitas $0,001<0,05$, sehingga dapat dikatakan bahwa dukungan emosional berpengaruh positif dan signifikan terhadap perilaku warga binaan pemasyarakatan di Lapas Kelas I Makassar. Hasil temuan empirik bahwa rata-rata warga binaan pemasyarakatan mendapatkan dukungan keluarga melalui dukungan emosional, hal ini dapat dilihat bahwa kehadiran keluarga membuat warga binaan merasa nyaman, Keluarga selalu mendengarkan curahan hati warga binaan. Kemudian teman-teman selalu datang menjenguk di Lapas, serta keluarga senantiasa memperlihatkan kepedulian kepada warga binaan pemasyarakatan yang ada di Lapas Kelas I Makassar. Penelitian ini sejalan dengan penelitian yang dilakukan oleh Rahmawati Yulianingsih (2018), hasil penelitian menemukan bahwa dukungan sosial keluarga berpengaruh terhadap perilaku non verbal seperti mengusap rambut, mencium kepala dan memeluk narapidana.

\section{2) Pengaruh dukungan instrumental terhadap perilaku warga binaan}

Hasil analisis koefisien regresi maka diperoleh hasil statistik untuk dukungan instrumental sebesar 0,234 serta memiliki nilai probabilitas $0,002<0,05$, sehingga dapat dikatakan bahwa dukungan instrumental berpengaruh positif dan signifikan terhadap perilaku warga binaan pemasyarakatan di Lapas Kelas I Makassar. Dari hasil penyebaran kuesioner maka diperoleh temuan bahwa rata-rata keluarga sudah memberikan dukungan instrumental kepada warga binaan di Lapas Kelas I Makassar, hal ini dapat dilihat bahwa keluarga selalu mengingatkan untuk terus berdoa kepada Allah, Keluarga memberikan semangat agar selalu kuat menghadapi cobaan ini. Kemudian keluarga selalu memberikan bantuan makanan kepada warga binaan, serta mengingatkan agar tidak perlu khawatir dengan keadaan keluarga di luar sana, sehingga hal ini memberikan perasaan tenang bagi warga binaan selama menjalani masa tahanan. Hasil penelitian ini sejalan dengan penelitian yang telah dilakukan oleh Muhammad Wahyudi (2018), dimana diperoleh temuan empirik bahwa dengan adanya dukungan sosial keluarga berpengaruh terhadap penyesuaian diri warga binaan pada Kasus Narkoba di Lapas Kelas I Malang.

\section{3) Pengaruh dukungan informasi terhadap perilaku warga binaan}


Dari hasil analisis koefisien regresi maka diperoleh hasil statistik untuk dukungan informasi sebesar 0,288 serta memiliki nilai probabilitas $0,000<0,05$. Hal ini dapat disimpulkan bahwa dukungan informasi memberikan pengaruh positif dan signifikan terhadap perilaku warga binaan pemasyarakatan kelas I Makassar. Hasil pengamatan yang dilakukan melalui penyebaran kuesioner maka diperoleh temuan-temuan bahwa keluarga selalu menasehati agar warga binaan selalu berpikir positif selama di Lapas, keluarga selalu mengingatkan untuk selalu sabar dalam menjalani tahanan di Lapas. Kemudian keluarga selalu memberikan arahan agar tidak terlalu berpikir atau mengingat keluarga di rumah, serta keluarga memberikan saran untuk selalu menjalankan ibadah selama berada di Lapas. Hasil penelitian ini relevan dengan penelitian yang dilakukan oleh Meiga Latifah Putri Permadin (2018), dimana hasil penelitian menemukan bahwa terdapat hubungan antara dukungan keluarga dengan penerimaan diri narapidana di Lembaga Pemasyarakatan Wanita Klas IIa Tangerang.

\section{4) Pengaruh dukungan motivasional terhadap perilaku warga binaan}

Hasil analisis koefisien regresi maka diperoleh hasil statistik untuk dukungan motivasional sebesar 0,291 serta memiliki nilai probabilitas $0,003<0,05$. Hal ini dapat disimpulkan bahwa dukungan motivasional berpengaruh positif dan signifikan terhadap perilaku warga binaan pemasyarakatan di Lapas Kelas I Makassar. Dari hasil pengamatan maka diperoleh temuan bahwa rata-rata keluarga sudah memberikan dukungan motivasional kepada warga binaan di Lapas Kelas I Makassar, hal ini dapat dilihat bahwa Keluarga memberikan keyakinan kepada warga binaan bahwa kelak akan mendapatkan remisi (potong tahanan), warga binaan selalu diberikan semangat untuk bangkit dalam menjalani kehidupan ini. Kemudian Keluarga selalu memberikan perhatian yang besar selama ditahan di Lapas I Makassar, begitu pula para warga binaan pemasyarakatan bersemangat kembali selama di Lapas dengan mengikuti segala kegiatan-kegiatan kerajinan tangan karena adanya motivasi dari keluarga. Penelitian ini sejalan dengan penelitian yang dilakukan oleh Rahmawati Yulianingsih (2018), hasil penelitian menemukan bahwa dukungan sosial keluarga melalui dukungan motivasional yang ditunjukkan oleh keluarga berupa pemberian dorongan dan semangat pada narapidana agar dapat menjalani kehidupan di Lembaga Pemasyarakatan dengan lapang dan menerima takdir yang diberikan oleh Allah SWT.

\section{KESIMPULAN DAN SARAN}

Berdasarkan hasil penelitian dan pembahasan maka dapat ditarik beberapa kesimpulan dari hasil analisis yaitu : Hasil analisis persamaan regresi maka dapat disimpulkan bahwa dukungan sosial keluarga ditinjau dari dukungan emosional berpengaruh positif dan signifikan terhadap perilaku warga 
binaan pemasyarakatan di Lapas Kelas I Makassar. Dari analisis koefisien regresi maka disimpulkan bahwa dukungan instrumental berpengaruh positif dan signifikan terhadap perilaku warga binaan pemasyarakatan di Lapas Kelas I Makassar. Berdasarkan hasil analisis regresi maka diperoleh temuan bahwa dukungan informasi berpengaruh positif dan signifikan terhadap perilaku warga binaan pemasyarakatan di Lapas Kelas I Makassar. Dari hasil analisis persamaan regresi maka disimpulkan bahwa dukungan motivasional berpengaruh positif dan signifikan terhadap perilaku warga binaan pemasyarakatan di Lapas Kelas I Makassar. Berdasarkan hasil pengujian secara simultan maka dapat disimpulkan bahwa dukungan emosional, dukungan instrumental, dukungan informasi dan dukungan motivasional berpengaruh secara bersama-sama atau serempak terhadap perilaku warga binaan pemasyarakatan di Lapas Kelas I Makassar. Dengan demikian hipotesis kelima terbukti kebenarannya. Saran-saran yang dapat diberikan sehubungan dengan hasil penelitian yang dilakukan adalah : Disarankan agar keluarga dapat mengajak teman-teman atau sahabat dari warga binaan untuk datang menjenguk dan memberikan semangat sehingga hal ini memberikan perasaan nyaman bagi warga binaan pemasyarakatan. Untuk meningkatkan dukungan instrumental, maka perlunya pihak keluarga apabila datang menjenguk dengan membawakan makanan kesukaannya, selain itu meyakinkannya untuk tidak memikirkan keluarga di luar, agar warga binaan merasa tenang selama menjalani masa tahanan. Kemudian untuk lebih meningkatkan perilaku yang baik bagi warga binaan pemasyarakatan maka disarankan sebaiknya keluarga yang datang selalu memberikan nasehat-nasehat dan arahan untuk selalu berpikir positif selama di Lapas. Disarankan pula agar pihak keluarga selalu memberikan keyakinan bagi warga binaan agar kelak mendapatkan remisi atau potong tahanan yang penting warga binaan memiliki perilaku yang baik selama menjalani hukuman di Lembaga Pemasyarakatan Kelas I Makassar.

\section{DAFTAR PUSTAKA}

\section{Jurnal}

Apollo \& A. Cahyadi (2012). Konflik Peran Ganda Perempuan Menikah yang Bekerja Ditinjau dari Dukungan Sosial Keluarga dan Penyesuaian Diri. Madiun : Program Studi Psikologi, Fakultas Psikologi, Universitas Katolik Widya Mandala Madiun.

Isnawati, D. dan S Rendi. (2013). Hubungan antara Dukungan Sosial dengan Penyesuaian Diri Masa Persiapan Pensiun pada Karyawan PT Pupuk Kaltim. Jurnal Psikologi Industri dan Organisasi. Vol. 1, Februari 2013, Hal. 1-6. Departemen Psikologi Industri dan Organisasi Fakultas Psikologi Universitas Airlangga. 
Kumalasari, F \& Latifah N. A. (2012). Hubungan Antara Dukungan Sosial Dengan Penyesuaian Diri Remaja Di Panti Asuhan. Jurnal Psikologi Pitutur. Volume 1 No.1. Hal 21-31

Meiga, L. dan P. Permadin (2018) Hubungan Dukungan Keluarga Dengan Penerimaan Diri Narapidana di Lembaga Pemasyarakatan Wanita Klas IIa Tangerang Jurnal Universitas Islam Negeri Syarif Hidayatullah Jakarta

Muhammad, W. (2018) Hubungan Dukungan Sosial Keluarga Terhadap Penyesuain Diri Warga Binaan Pada Kasus Narkoba di Lembaga Pemasyarakatan Kelas I Malang. Jurnal Universitas Islam Negeri Maulana Maliki Ibrahim Malang

Rahmawati, Y. (2018) Dukungan Sosial Keluarga Pada Narapidana di Lembaga Pemasyarakatan Klas IIb Klaten.. Jurnal Institute Agama Islam Negeri Surakarta.

Setyaningrum, A. (2015). Pengaruh Dukungan Sosial Orang Tua Terhadap Motivasi Berprestasi Siswa Kelas V Sekolah Dasar Di Gugus Hasanuddin Kabupaten Cilacap. Jurnal (online). Yogyakarta: Fakultas Ilmu Pendidikan Universitas Negeri Yogyakarta. Dalam (http://www.enprints.ac.id diakses pada 11 Desember 2016)

Tarmidi dan A. R. R. Rambe. (2010). Korelasi Antara Dukungan Sosial Orang Tua dan Self-Directed Learning pada Siswa SMA. Jurnal Psikologi Vol. 37, No. 2, 216-223, Desember. Fakultas Psikologi Universitas Sumatera Utara.

\section{Buku}

Arikunto, Suharsimi. 2014. Prosedur Penelitian Suatu Pendekatan Praktik. Penerbit : Rineka Cipta. Jakarta

Ghozali Imam, 2018, Aplikasi Analisis Multivariate Dengan Program IBM SPSS 25, edisi kesembilan, cetakan kesembilan, Badan Penerbit : Universitas Diponegoro Semarang

Helmawati. 2014. Pendidikan Keluarga. Penerbit : Remaja Rosdakarya. Bandung

Notoatmodjo, S, 2012, Promosi Kesehatan dan Perilaku Kesehatan, Penerbit : Rineka. Cipta. Jakarta

Pardede, R. dan Manurung, R. 2014. Analisis Jalur Teori dan Aplikasi dalam. Riset Bisnis. Penerbit : Rineka Cipta. Jakarta

Sugiyono, 2016, Metode Penelitian Administrasi dilengkapi dengan Metode R \& D, penerbit : Alfabeta, Bandung.

Undang-Undang Nomor 12 Tahun 1995 tentang Pemasyarakatan

Yusuf, Syamsu. 2011. Psikologi Perkembangan Anak dan Remaja. Bandung : Penerbit : Remaja Rosdakarya. 